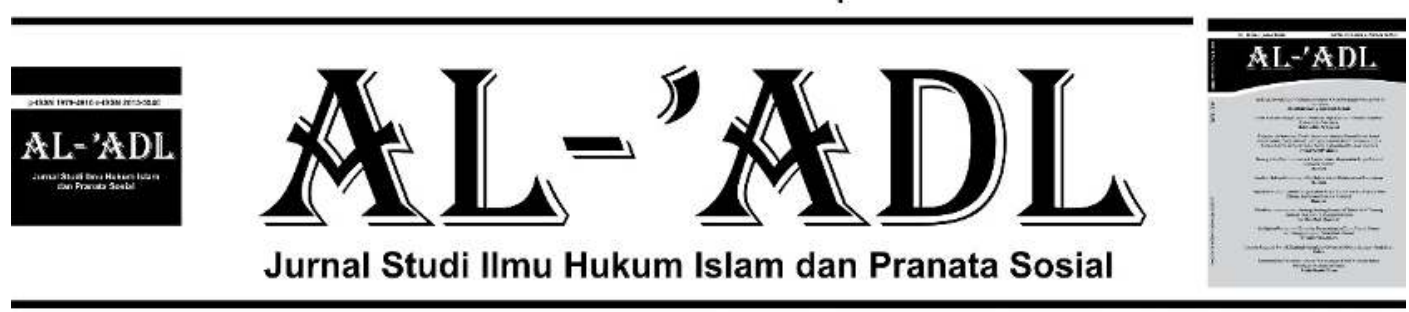

journal homepage : ejournal.iainkendari.ac.id/al-adl

\title{
Customary Payment to Achieve A Justice in The Land Disputes
}

\section{Marlin ${ }^{1}$, Farida Patittingi ${ }^{2}$, Suriani Bt Tolo ${ }^{3}$}

${ }^{1}$ Program Studi Hukum, Magister Hukum, Universitas Sulawesi Tenggara, Kendari, Indonesia

${ }^{2}$ Program Studi Ilmu Hukum, Fakultas Hukum, Universitas Hasanuddin, Makassar, Indonesia

${ }^{3}$ Program Studi Hukum, Magister Hukum, Universitas Sulawesi Tenggara, Kendari, Indonesia

E-mail: marlinadvokat@gmail.com ${ }^{1}$ 60suriani@gmail.com ${ }^{2}$

patittingi@yahoo.co.id ${ }^{3}$

\begin{tabular}{l}
\hline ARTICLE INFO \\
\hline Article History : \\
Received: 2021-01-07 \\
Accepted: 2021-01-08 \\
Published: 2020-01-27
\end{tabular}

Keywords :

Customary Payments, Land Dispute, Tolaki Indigenous People

(C) 2020 Al-'Adl. All rights reserved

\begin{tabular}{l} 
ABSTRACT \\
\hline The indigenous people of South Konawe highly \\
uphold the Tolaki customary law from ancient times \\
to the present, namely through the Kalosara media, \\
which is considered very sacred to its existence. Land \\
dispute resolution through customary payment has a \\
purpose to restore disturbed conditions caused by the \\
disputing parties. This research examines and \\
describes the implementation of customary payments \\
for land disputes, whether it can fulfill a sense of \\
justice for the indigenous people of South Konawe. \\
The research uses some secondary data through \\
literature studies and primary data through the \\
interview. The result indicates that the customary \\
payment in giving a sense of justice in land disputes \\
in South Konawe is considerably applicable. \\
However, a comprehensive study is needed to find the \\
justice which is aspired by the Tolaki Indigenous \\
People in South Konawe.
\end{tabular}




\section{A. Introduction}

Indigenous peoples uphold the principles, beliefs, and laws they have. They do not easily accept the external influences that are considered new to them. Old beliefs are always held tightly and obeyed from generation to generation. The pattern of thinking and speaking is modest without even thinking further and they can decide something taboo because of their belief. This is part of the characteristics of indigenous people who are close-minded. ${ }^{1}$

Customary law communities are groups of people who are organized, live in a certain area, have their power, and have their wealth in the form of visible and invisible objects, where the members of their respective units experience life in society as common as nature of nature and not one of the members has the thought or inclination to dissolve the bond established or leave it forever. ${ }^{2}$

Customary law does not recognize acquisitive institutions, which are known in customary law as rechtsverwerking institution, where in the past, it was the cause of loss of land rights if the land concerned has not been cultivated by the right holder for a long time and is controlled by other parties through acquiring rights in good intention. ${ }^{3}$

For the community, the land is seen as an eternal treasure because it will not be destroyed under any circumstances, besides that land functions as a place to live for community members and a place for them to seek life and as a place where they will be buried when they die. ${ }^{4}$ So that in the life of the Tolaki indigenous people in South Konawe, it is very sensitive if the land they use as a residence or the land which is used as a plantation is taken over or taken by other people and other fellows.

The customary law communities of Tolaki in Konawe Selatan have customary rules or customary law that differ from one region to another in terms of customary payments in general as a requirement or customary payments as a customary reaction in resolving land disputes. If the Tolaki indigenous people are faced with land disputes, the normative law which we know has always been

${ }^{1}$ Ahyuni Yunus dan Ahmad Ali Muddin, "Penyelesaian Sengketa Tanah Ulayat yang Telah Bersertifikat Berdasarkan Hukum Adat Malind - Anim", Kertha Patrika, Vol. 41, No. 3, Desember 2019, p. $209-210$.

${ }^{2}$ Munir Salim, "Adat Sebagai Wadah Perekat untuk Mempertahankan Persatuan RI", Jurisprudentie, Vol. 3, No. 1, Juni 2016, p. 116.

${ }^{3}$ Indri Hadisiswati, "Kepastian Hukum dan Perlindunganhukum Hak Atas Tanah", Ahkam, Vol. 2, No.1, Juli 2014, p. 118 - 147.

${ }^{4}$ Ratna Rahman, "Konflik Masyarakat dengan Pemerintah (Studi Kasus Sengketa Tanah Adat)", Sosioreligius, Vol. 3, No. 1, Juni 2017, p. 43. 
at the forefront of its resolution will be put aside. For indigenous peoples, normative law is very troublesome, tiring for those who dispute, and the results of the decisions for the indigenous peoples of Tolaki are felt to be very unfair.

The Tolaki indigenous people in South Konawe if there are land disputes or other disputes, prioritize customary settlement because according to the Tolaki indigenous people in South Konawe all problems on this earth that occur can be resolved customarily because the customary settlement is more valuable than traditional settlement. litigation, the values contained in customary settlement through the Kalosara media contain Divine Values (Pombesimeena), Mutual Value (Mepokoaso), Self-Esteem (Kohanu) Values of Chastity and Justice (Ate Pute Penao Moroa). These values make cultural values for the Tolaki indigenous people so that if they are violated, it will undoubtedly bring deep misery and sorrow to the offender. By the philosophy of the Tolaki indigenous people, namely "Inae Kona Sara Iepinesara, Inae Lia Sara Ieipinekasara" (Whoever respects the customary law will be respected, but whoever does not respect custom will never be respected).

In the customary law community of Tolakinese people from South Konawe, it is important to note that in the customary law if a dispute occurs, customary payments can arrange a magical balance or restore a situation considered disturbed or damage the balance of the community, as well as a reaction or custom correction in settling disputes that occur. among indigenous peoples as a form of justice. This act of customary reaction can not only be imposed on the perpetrator but can also be imposed on his relatives or family and may even be imposed on the community concerned to achieve a balance and resolve the issue. ${ }^{5}$.

In line with customary payments on land disputes that occur in the indigenous people of South Konawe, it is very effective in restoring a situation that damages the balance of the community in general, the implementation of which is usually carried out by the customary head or customary officials.

This fact is of course based on and related to the basic value or philosophy of customary payments or customary reactions, namely, to achieve the balance of the disturbed community because in the view or mindset of society all events can be seen as a sign of either positive or negative. This paper will discuss the extent to which customary payments in land disputes can fulfill a sense of justice for indigenous people in South Konawe.

5I Made Widnyana, 1993, Kapita Selekta Hukum Pidana Adat, PT Eresco, Bandung, p. 5. 


\section{B. Discussion}

The basis of the implementation of customary law is that the values and attitudes of customary law are very identical and are even reflected from Pancasila or the five basics of principles of Indonesia. For example, religion, humanity, cooperation, vote, and discussion, as well as justice. Thus, Pancasila is a crystallization of customary law. The basis for the application of customary law in terms of the philosophy of customary law that lives grows, and develops in Indonesia by the flexibility, and the values of Pancasila, as stated in the ideals of law and state law in the opening of the 1945 Constitution. The 1945 Constitution only creates the main ideas which cover the mystical atmosphere of the 1945 Constitution. These principles animate the ideals of state law and law, both written and unwritten. In the preamble of the 1945 Constitution, the main ideas that animate the ideals of the country's basic law are Pancasila. The affirmation of Pancasila as a source of the legal order is very meaningful for customary law because customary law is rooted in real and living culture among the people and reflects the personality of the Indonesian people and nation. Thus, customary law is philosophically a law that applies according to Pancasila as a way of life or the philosophy of life of the Indonesian nation. ${ }^{6}$

In line with customary payments on land disputes in South Konawe, they also adhere to the values of Pancasila as well as the culture of the Indonesian nation which also contains the very high culture of the Tolaki indigenous people in South Konawe. The values reflected in the Kalosara media are Divine Value (Pombesimeena), Mutual Value (Mepokoaso), Self-Esteem (Kohanu) Value, and Justice (Ate Pute Penao Moroa). The values contained in Kalosara for the Tolaki indigenous people can be interpreted as being equal to the values that exist in their beliefs. Therefore, if it is violated, it will undoubtedly bring great misery and sorrow to the offender and his community.

Kalosara media function both as a cause as well because of an event. As a cause: In a series of weddings, the kalosara must be held as the main traditional instrument and if the kalosara does not exist, the event cannot be held. Meanwhile, as a result: if two people disagree, then to reconcile a kalosara must be held. Finally, whatever the activities of the Tolaki community, then kalosara

p. 14 .

${ }^{6}$ Wignjodipoero, 1998, Pengantar dan Asas - Asas Hukum Adat, Haji Mas Agung, Jakarta, 
must exist, so that all activities of a person and group of people must always rely on kalosara. ${ }^{7}$

In connection with the explanation above, it was also emphasized by Dimanto, Al Hadra that the existence of Kalosara in the Tolaki Tribe community has become evidence of being able to resolve problems that occur in society. ${ }^{8}$

The Tolaki people have a philosophy, namely "Inae Kona Sara Iepinesara, Inae Lia Sara Ieipinekasara" (Whoever respects adat will be respected, but whoever does not respect custom will never be respected). The basic philosophy of the Tolaki tribal indigenous people highly upholds the resolution of customary violations or land disputes in customary law communities in South Konawe, The Tolaki tribe makes Kalosara a customary law that has a very sacred function, is obeyed and respected. Therefore, Tolaki people adhere to it. In several cases that occurred and involved Kalosara, both individuals, families, and groups in the Tolaki community.

Therefore, in settling customary violations or land disputes that occur in general, customary law communities prefer to settle them according to their customary legal institutions. The choice of the settlement of customary violations or disputes by custom is based on several basic reasons, namely':

1) There is a belief that their customs are the incarnation of the creator of the universe, which is always related to the type of leadership, where the highest traditional leader is a role model for the community and even an intermediary for a god.

2) In particular, settlement of customary violations or land disputes is closely related to the dignity, honor, and dignity of family or relatives and even the community as a whole. Therefore, a case of customary violation is prioritized to be resolved by the custom in one's environment rather than being resolved outside an environment that seems to open up shame or embarrassment that will be known by outsiders.

3) In the case of settlement of customary violations or disputes, the elements of kinship also can influence or determine something. Therefore, the settlement

${ }^{7}$ Amiruddin, I Ketut Suardika, dan Anwar, "Kalosara di Kalangan Masyarakat Tolaki di Sulawesi Tenggara", Mudra, Vol. 32, No. 1, Mei 2017, p. 217.

${ }^{8}$ Dimanto dan Al Hadra, "Fungsi Kalosara Pada Masyarakat Tolaki di Desa Lalonggasu Kecamatan Tinanggea Kabupaten Konawe Selatan”, Historical Education, Vol. 5, No. 2, April 2020, p. 76.

${ }^{9}$ Kadir Katjong, 1977, Penyelesaian Sengketa Secara Adat (Suatu Studi Kasus Penyelesaian Sengketa Perkawinan di Desa Nafri Jayapura, Irian Jaya, Tesis, Program Pascasarjana Program Studi Antropologi, Universitas Indonesia, Jakarta, p. 113 - 117. 
of violations or disputes carried out customarily is felt to be more appropriate and more flexible because they are still in a social environment that is completely familiar to the disputing parties. In such an environment, the parties will feel free to say everything they think (they want) about matters related to customary violations or disputes that have occurred. Therefore, in customary dispute resolution, the role of communal kinship can function or act as a support or pulley in dispute resolution.

4) Any settlement of customary violations or disputes resolved by custom will be culturally felt more following the sense of justice or feelings of justice of the local customary law community so that it can achieve the balance in the customary law community itself, because customary dispute resolution through customary leaders or councils local customs, they are the people who can understand and know the sense of justice that exists in their community, they are the ones who know the soul or spirit of their people in everyday social life.

5) According to the local customary law community's view that under any circumstances they must be able to solve their problems or problems that occur in their community. If the problem is submitted to be resolved outside of their social environment, it means that traditionally they feel ashamed because they are considered unable to solve their problems or problems. Therefore, life and death, difficulty and pleasure in every problem must be resolved by custom because every custom violation or any dispute the customary leadership through the customary council always tries to resolve it completely. This principle is the self-identity or dignity of the customary law communities in South Konawe because it is related to the honor and dignity of the individual,

The reasons for the choice of the settlement of customary permits or customary disputes above show that in a situation of legal pluralism or legal pluralism, the customary law communities in South Konawe still have the principle or tendency to choose their customary legal institutions in resolving customary violations or land disputes that have occurred because they feel that more in their favor. Besides, the advantages of customary dispute resolution through customary councils or customary courts compared to formal courts are:

1) Easy to access, fast and cheap. Non-state courts are more accessible, faster, and cheaper than state courts. This ease of access is since customary chiefs and traditional leaders live in the local community, are known by the community, and easy to find 
2) Maintaining social harmony and harmony is highly prioritized in the life of customary law communities, and this will be easily created because customary courts adhere to the principle of restorative justice. In restorative justice returns conflicts to the parties most affected, namely victims, perpetrators, and community interests.

3) Flexibility in process and substance. In the process of resolving justice disputes, it is the result of an agreement with the parties or victims and perpetrators, not based on definite or legal rules. All cases can be resolved deliberately to get a balance or restore the situation.

4) Based on local authority and legality, customary law communities and traditional communities generally prefer customary courts to state courts mainly because of the authority of the perpetrators within the local customary law community to solve problems and implement decisions. As parties who have socio-cultural legitimacy at the local level, justice-seekers will be satisfied with the decisions made by these authorities. In the indigenous peoples of South Konawe, the perpetrators of customary justice are considered to have supernatural powers, thereby increasing their capacity to resolve local disputes and ensure their implementation.

5) The decision that is handed down cannot be contested because it is final, and those who have litigation, both from the reporting party and the reported party, are obliged to carry out and obey it sincerely and with a full sense of responsibility because the indigenous people believe in the consequences of not carrying out what has been decided by the customary judge.

In the settlement of customary violations or disputes in the customary law community in South Konawe, the role of family or kinship to support the disputing parties provides strong support for the parties in dispute resolution from beginning to end until a customary sanction or fine is imposed by the customary council. Family or kinship support like this shows a strong communal or togetherness bond in all aspects. Therefore kinship support is an obligation that symbolizes the collective as the opposite of individuals, and the obligation is not to satisfy oneself, but as a pulley or support as a principle or strong collective value in supporting all activities in the customary law community, including in resolving disputes that occur.

The fact that this kinship support is a matter that contributes to a resolution of customary violations or disputes, thus the above illustrates to us that in resolving a customary violation or dispute not only is it related to legal issues, but also concerns relations persistent social relationships. 
In connection with the settlement through customary law, Basrawi points out that it is legal certainty as to the basis for the legitimacy of the national legal justice system which aims to create order and restore lost balance in society. ${ }^{10}$

In connection with the above expression of feelings of justice, settlement of customary violations committed by custom, where the decisions passed by customary leaders through the customary council are felt to be more in line with the feelings of justice of the local customary law community because it is generally acceptable to all parties, especially those who dispute.

Settlement of customary violations or disputes committed by customary law communities in South Konawe according to Sally Falk Moore 'is a semiautonomous social field where the field can produce rules from within even though it is vulnerable to rules and other forces that come from from the outside world that surrounds them. ${ }^{11}$

What is stated by Moore above shows that the customary law communities in South Konawe have their own rules (which come from within), which can be used to resolve any problems or disputes that occur among their citizens without choosing another law. (formal) that surrounds and applies to them as citizens. This shows that the customary rules originating from within the customary law community are still strong or still functioning because they still show effective internal forces that determine how to submit to their citizens, especially through the Puutobu adat leadership (adat council) in resolving customary violations or the dispute that occurred.

As a customary leader (Puutobu) in the customary law community in South Konawe, in this case, a Puutobu in carrying out the function of resolving land disputes or other customary violations in the customary law community is always symbolized as sun, earth, Anoa, Rattan, and water.

The stages of land dispute resolution through the Customary Council according to the results of Mr. Nurdin Mangidi's Puutobu interview are carried out in the following stages:

1. There is a report or complaint to Puutobu / Toono Motuo from the party who feels aggrieved (the Rapporteur).

${ }^{10}$ Basrawi, "Kepastian Hukum dalam Penyelesaian Kasus Pidana melalui Hukum Adat Ditinjau dari Hukum Nasional”, $A l$ - 'Adl, Vol. 13, No.1, Januari 2020, p. 70.

${ }^{11}$ Sally Falk Moore, 1993, Hukum dan Perubahan Sosial: Bidang Sosial Semi-Otonom Sebagai Suatu Topik Studi yang Tepat, dalam Ihromi (ed), Antropologi Hukum Sebuah Bunga Rampai, Yayasan Obor, Jakarta, p. 150. 
2. After that, the Customary Council through the customary leadership submits the report or complaint to the Government and then the Government and the customary council determine the time of day to start the settlement of the customary violation or dispute.

3. Determination of the time for settlement of customary violations or disputes is conveyed by the customary council to both parties (along with their families/relatives)

4. The customary council conducts customary sessions at the specified time. The custom of Mombesara and Kalosara is directly confronted by the customary recipient, namely Puutobu (Hakim), while the carrier of the kalosara is Pabitara (traditional lawyer) with the essence of talking about the intent and purpose of bringing down Kalosara.

5. Reporters and Reported Parties must be accompanied by each family of Tolea and Pabitara (Traditional Lawyers)

6. The customary session opened (started) Puutobu traditional leader as (Judge) Responded, all members were allowed to speak.

7. After the statement or explanation from the reporting party has been completed, the Puutobu adat leadership asks the perpetrators of customary violations to provide information or explanations in connection with the customary violations they have committed.

8. If both parties have traditional leadership witnesses as chairman, ask the witnesses to give their testimony following what they have seen, heard, or known regarding the customary violation.

9. After the testimony of witnesses from both parties, the customary council asks questions to both parties and then the customary council submits bids according to the victim's request and the consideration of the customary council to be mutually agreed upon, if there is no agreement, the customary council through Puutobu (Hakim) will decide.

10. The decision of the customary council was taken based on the results of deliberations to reach the consensus of the members of the customary court which was pronounced by Puutobu (Hakim).

11. The court decision is binding and cannot be contested by anyone, the sanctions for customary violators are payment of fines (Peohala), forced labor (Pinoko Mbei'indio), expelled from the village (Tinamba Lako), Sentenced to death (pinepate) before but now it has been eliminated.

One example of a case that occurred in South Konawe according to the results of an interview with Puutobu (a traditional figure) is as follows: 'Darwis 
carried out and removed Risman's land boundary markers. Seeing this incident, Risman was not happy, thinking Risman cursed Darwis' brother and threw away the land stake that had been installed by Darwis, seeing that Darwis' brother fought Risman with harsh words, then Risman beat and cut Darwis' brother at part of his arm, this case was then resolved according to custom through LAT and Risman was subject to sanctions with the payment of a fine in the form of Rp. 15,000,000 with a cow, a sarong, a kettle, a machete, a cloth, and Darwis' brother was subject to sanctions return the actual limit according to the decision of the customary council.

The form of payment of customary fines to customary law communities in South Konawe can be in the form of objects, buffaloes, clothes, goods, and nowadays a sum of money is added, which varies or varies between customary law communities in South Konawe, depending on the type of violations.

Traditionally the customary payment process uses the principle of deliberation to reach a consensus. The custom payment processes are:

a) The victim's party filed a suit against the perpetrator.

b) The perpetrator responded to the demands put forward by the victim.

c) After there is an agreement, this is an agreement and legalized

d) In the process of implementing custom payment, goods that have been agreed upon are submitted before the customary assembly Implementation of customary payments, the parties are asked to check the accuracy of customary payment goods according to the agreement

e) An apology was made from both parties then the custom payment items from both parties were handed over.

f) After that, do Mosehe Wonua (resolve the situation because of the problem). Continue with Praying and shaking hands as well as having a meal together.

In connection with the customary law, if one of the disputing parties does it again, the penalty is being expelled from the village. So that the importance of maintaining and overseeing the results of the customary court is an instrument in maintaining the unity of the results of the determination of a peace court institution between members of the customary law community in the existing customary law community. In general, every human being has 
interests, both group interests, and individual interests, to fulfill and protect those interests, humans need other humans ${ }^{12}$

The legal culture of land dispute resolution among customary law communities in South Konawe has been carried out from the time of their ancient ancestors to the present day. And this Tolaki customary law is derived from the holy book of the Koran, one of its sources can be seen from the value of Religio Magis (Divinity) so that the indigenous peoples of South Konawe strongly believe in it.

From the point of view of Kamaruddin, it is revealed that if there is a law that can provide benefits in the world and guarantees happiness in the hereafter, why should we choose a law other than Islamic law. Because Islamic law is a law originating from Allah and His Messenger who guarantees justice and safety in the world and the hereafter. ${ }^{13}$

So that the payment of this customary fine aims to erase emotion or anger and at the same time as a tool or means of peace in reconciling the two parties. As the Qur'an teaches it. This can be seen where the payment of customary fines results in peace, and between the two parties, not as enemies but as a family by shaking hands and hugging then continuing with prayer together, after which both parties prepare food to eat together as a form of peace.

\section{Conclusion}

Customary payments for land disputes in the Tolaki indigenous community in South Konawe can fulfill a sense of justice because of the cultural values contained in the Kalosara media which are sacred to the Tolaki community in South Konawe. Kalosara for the Tolaki tribe must be obeyed, and obeyed, traditional figures who play a role in carrying out their functions, especially in solving problems that occur in the Tolaki community, All Tolaki people adhere to the principle of harmony, the principle of decency, the principle of harmony and responsibility. by customary judges. So that the settlement of land disputes through customary payments makes the Tolaki community in South Konawe respectable and dignified.

${ }^{12}$ Mulyadi Golap dan Anisah Maya Djafar Umpain, "Eksistensi Lembaga Masyarakat Adat Mala Moi dalam Pembagian Harta Warisan Tanah Adat Marga Osok Malaimsimsa di Kota Sorong", Justisi, Vol. 4, No. 2, Juli 2018, p. 84.

${ }^{13}$ Kamaruddin, "Penerapan Hukum Waris Pada Masyarakat Kota Kendari (Studi Banding Hukum Adat, Islam dan Perdata Barat)”, $A l$ - 'Adl, Vol. 1, No. 2, Juli 2008, p. 14. 


\section{References}

\section{Book}

Moore, Sally Falk, 1993, Hukum dan Perubahan Sosial: Bidang Sosial Semi Otonom Sebagai Suatu Topik Studi yang Tepat, dalam Ihromi (ed), Antropologi Hukum Sebuah Bunga Rampai, Yayasan Obor, Jakarta.

Widnyana, I Made, 1993, Kapita Selekta Hukum Pidana Adat, PT Eresco, Bandung.

Wignjodipoero, 1998, Pengantar dan Asas - Asas Hukum Adat, Haji Mas Agung, Jakarta.

\section{Journal}

Amiruddin, I Ketut Suardika, dan Anwar, "Kalosara di Kalangan Masyarakat Tolaki di Sulawesi Tenggara", Mudra, Vol. 32, No. 1, Mei 2017.

Basrawi, "Kepastian Hukum dalam Penyelesaian Kasus Pidana melalui Hukum Adat Ditinjau dari Hukum Nasional”, Al - 'Adl, Vol. 13, No.1, Januari 2020.

Dimanto dan Al Hadra, "Fungsi Kalosara Pada Masyarakat Tolaki di Desa Lalonggasu Kecamatan Tinanggea Kabupaten Konawe Selatan”, Historical Education, Vol. 5, No. 2, April 2020.

Golap, Mulyadi dan Anisah Maya Djafar Umpain, "Eksistensi Lembaga Masyarakat Adat Mala Moi dalam Pembagian Harta Warisan Tanah Adat Marga Osok Malaimsimsa di Kota Sorong”, Justisi, Vol. 4, No. 2, Juli 2018.

Hadisiswati, Indri, "Kepastian Hukum dan Perlindunganhukum Hak Atas Tanah", Ahkam, Vol. 2, No.1, Juli 2014.

Kamaruddin, "Penerapan Hukum Waris Pada Masyarakat Kota Kendari (Studi Banding Hukum Adat, Islam dan Perdata Barat)", $A l$ - 'Adl, Vol. 1, No. 2, Juli 2008.

Rahman, Ratna, "Konflik Masyarakat dengan Pemerintah (Studi Kasus Sengketa Tanah Adat)", Sosioreligius, Vol. 3, No. 1, Juni 2017.

Salim, Munir, "Adat Sebagai Wadah Perekat untuk Mempertahankan Persatuan RI”, Jurisprudentie, Vol. 3, No. 1, Juni 2016.

Yunus, Ahyuni dan Ahmad Ali Muddin, "Penyelesaian Sengketa Tanah Ulayat yang Telah Bersertifikat Berdasarkan Hukum Adat Malind - Anim", Kertha Patrika, Vol. 41, No. 3, Desember 2019.

\section{Thesis}


Katjong, Kadir, 1977, Penyelesaian Sengketa Secara Adat (Suatu Studi Kasus Penyelesaian Sengketa Perkawinan di Desa Nafri Jayapura, Irian Jaya, Tesis, Program Pascasarjana Program Studi Antropologi, Universitas Indonesia, Jakarta. 